gone, / And I am struck with sorrow' [v.vi.147-8]. This is partly a play about the destructive effects of anger.

\title{
Language and acting as deception
}

Since the popularity of post-modern fiction and critical theories which see a text as a construction, it has become commonplace to say that literature can either imitate reality or be concerned with the art of art and that it more likely, or more interestingly, is concerned with the latter. Shakespeare's plays always have a concern with the nature of language, spectacle, playing and directing, treating each as a danger, an untruth, a potential source of evil. Perhaps he had a writer's distrust for words? The villains of his plays - Richard III, Iago, Edmund - are the wordsmiths, the ones who make up the plots, who arrange scenes that deceive. The best speakers, the playwrights, are evil. If they are not (Prospero is a major exception) they are aware of the potential of art to do evil. Coriolanus is filled with playlets, rehearsals, roles, acting. It is also a play where Shakespeare does not fall back on a possible devil theory of evil. Richard III and Iago are in part traditional vice characters. Iago gives many explanations for his conduct but he is finally someone whose malcontentedness seems devilish rather than of human origins. In the case of the tribunes, the nobles, Aufidius, there are no devils; they are driven by recognisable human ambitions, the desire for power, fear, envy. The selfreferentiality of the play is not therefore an abstract theoretical concern with the art of drama; rather the play questions whether language, the ability to deceive others, the art of falsifying may in itself be a moral danger, not only untrue but evil in origin because false and most likely used to deceive the innocent. Consider that opening scene in King Lear. Language is used to lie, truth cannot flatter. Coriolanus' best quality is that he cannot lie. What he says may be dislikeable, hateful, but it is not flattery, does not cover secret aims. 